\title{
Organisasi Kepemudaan yang Efektif dan Efisien dalam Meningkatan Partisipasi Masyarakat Desa Darungan Kecamatan Wlingi
}

\author{
Ardina Prafitasari \\ Universitas Islam Balitar \\ e-mail: ardinafita6@gmail.com \\ Ferida Asih Wiludjeng \\ Program Studi Ilmu Administrasi Negara, Universitas Islam Balitar \\ e-mail: wiludjeng02@gmail.com
}

\begin{abstract}
ABSTRAK
Penelitian ini bertujuan untuk mengetahui bagaimana peran Organisasi Bina Pemuda dalam meningkatkan partisipasi masyarakat dalam mengikuti kegiatan-kegiatan yang diadakan di Desa Darungan, Kecamatan Wlingi, Kabupaten Blitar. Dalam. Metode penelitian yang digunakan dalam penelitian ini adalah metode kualitatif dimana dalam metode ini menghasilkan data deskriptif berupa kata-kata tertulis atau lisan dari orang-orang dan perilaku yang diamati sehingga diperoleh informasi, keterangan dan berupa hasil-hasil pengamatan. Dalam penelitian ini penulis mengamati secara langsung saat Organisasi kepemudaan melakukan kegiatan bermasyarakat, dan juga melakukan wawancara dengan ketua organisasi serta salah satu anggota Organisasi Bina Pemuda yang aktif dimana hasilnya nanti akan dipaparkan dalam penjelasan berdasarkan penelitian tersebut.

Hasil dari penelitian tersebut menunjukkan bahwa dalam kegiatan yang diadakan di desa oleh Organisasi ini masyarakat desa telah ikut berkontribusi dalam banyak kegiatan di masyarakat. Dengan mengimplementasikan program kerja organisasi ini ke dalam bentuk sebuah kegiatan akan menunjukkan keberhasilan organisasi ini dalam meningkatkan partisipasi masyarakat di kegiatan yang ada di desa. Dengan ikut berpartisipasinya pemuda-pemuda di organisasi ini maka akan menumbuhkan jiwa sosial dan kesedaran betapa pentingnya ikut berpartisipasi dalam kegiatan masyarakat. Masyarakat akan lebih aktif dan desa pun menjadi ramai dengan kegiatan-kegiatan yang positif.

Kata kunci : Pemuda, Partisipasi masyarakat
\end{abstract}


ABSTRACT

This study aims to determine how the role of Youth Development Organization in improving community participation in following the activities held in the Village Darungan, District Wlingi, Blitar. In. The research method used in this study is a qualitative method where in this method generate descriptive data in the form of written words or oral from the people and behavior observed so that obtained information, description and in the form of results of observation. In this study the authors observed directly when youth organizations engaged in community activities, and also conducted interviews with the head of the organization and one ofthe active members of the Youth Development Organization where the results will be presented in the explanationbased on the research.

The results of the study indicate that in the activities held in villages by these organizations villagers have contributed to many activities in the community. By implementing the work program of this organization into the form of an activity will demonstrate the successof this organization in increasing communityparticipation in activities in the village. By joining the participation of youths in this organization will grow the social soul and the awareness of the importance of participating in community activities. The community will be more active and the village becomes crowded with positive activities.

Keywords : Youth, increasing participation

\section{PENDAHULUAN}

Pergaulan yang salah meruan salah satu penyebab generasi muda terjerumus dalam perilaku yang menyimpang. Perilaku menyimpang tersebut diharapkan tidak sampai masuk dalam kebiasaan generasi muda sebagai penerus bangsa, karena merekalah yang akan menjadi pemimpin masa depan bangsa. Kenyataan telah menunjukkan perubahan dengan ditandai kemajuan IPTEK yang mengakibatkan perubahan social. Dengan semakin canggih teknologi komunikasi dan informatika membuat perubahan di masyarakat dengan begitu cepat dan 
mereka harus mengikutinya agar tidak tertinggal dengan Negara lain (Basri Hasan, $2004: 12-13$ )

Masa remaja adalah masa yang penuh dengan keindahan, pada masa tersebut mereka belajar untuk menyiapkan diri menghadapi tugas-tugas di masa yang akan datang, yaitu masa dewasa dan masa tua. Disamping belajar mereka juga perlu mengisi hari-hari mereka dengan latihan-latihan kerja sehingga memiliki ketrampilan kerja yang diharapkan dan dimiliki oleh setiap orang yang membuat mereka mencapai kesuksesan dalam kerja (Badiyanta, Zulkifli dan Karsono, 2009 : 63)

Pembinaan generasi muda agar mereka tidak terjerumus ke dalam perilaku yang menyimpang sangat diperlukan. Bahkan mereka harus diberi bekal mengenai dasar perkembangan kepribadiannya sejak dini agar mereka tahu dan bisa membedakan mana yang baik dan mana yang tidak. Pembinaan kepada para pemuda bisa diberikan melalui organisasi. Jika di sekolah formal mereka bisa mengikuti organisasi OSIS, akan tetapi jika kita berbicara masalah organisasi non formal maka organisasi-organisasi yang ada di lingkungan sekitar mereka seperti organisasi-organisasi kepemudaan yang ada di desa. Karena dengan mengikuti sebuah organisasi mereka akan lebih terhindar dari hal-hal negatif dan lebih menghabiskan waktu yang bersifat positif misal di kegiatan-kegiatan sosial

Organisasi-organisasi di desa dituntut memiliki peranan penting dalam membangun desa, tetapi tidak menutup kemungkinan bahwa masih banyak pemuda-pemuda di desa yang masih kurang aktif dalam mengikuti organisasi maupun ikut dalam kegiatan bermasyarakat. Dan juga rendahnya partisipasi masyarakat dalam mengikuti kegiatan di desa juga kiranya perlu ditumbuhkan melalui jiwa-jiwa pemuda yang ada di desa.

Dengan melihat permasalahan di atas maka terbentuklah sebuah organisasi kepemudaan yang berperan aktif dalam mengadakan kegiatan di masyarakat yaitu Organisasi Bina Pemuda. Organisasi ini adalah organisasi perkumpulan para pemuda di mana mereka bisa menyalurkan aspirasi dan kreatifitas mereka dalam kegiatan masyarakat. Mereka dapat mengadakan kegiatan-kegiatan yang bersifat positif yang bisa membuat masyarakat aktif di kegiatan sosial atau di kegiatan- 
kegiatan desa. Dengan diadakannya sebuah kegiatan oleh organisasi Bina Pemuda ini diharapkan bisa menumbuhkan jiwa sosial dan mereka akan sadar betapa pentingnya ikut berpartisipasi di kegiatan masyarakat. Oleh karena itu penulis tertarik untuk melakukan penelitian mengenai peranan organisasi kepemudaan di desa terhadap partisipasi kegiatan masyarakat dan membuatnya menjadi sebuah jurnal yang berjudul Peranan Organisasi Kepemudaan dalam Peningkatan Partisipasi di Kegiatan Masyarakat di Desa Darungan Kecamatan Wlingi.

\section{TINJAUAN PUSTAKA}

\section{Pengertian Peranan}

Peran Merupakan aspek dinamis kedudukan (status). Seseorang melaksanakan hak dan kewajibannya sesuai dengan kedudukannya maka dia bisa disebut menjalankan suatu peranan. Peranan yang melekat pada diri seseorang harus dibedakan dengan posisi dalam pergaulan kemasyarakatan, posisi seseorang dalam masyarakat meruan unsur statis yang menunjukan tempat individu pada organisasi masyarakat. (Soekanto, $1990: 243$ )

Dalam Kamus Besar Bahasa Indonesia, peranan mempunyai arti tindakan yang dilakukan seseorang atau sekelompok orang dalam suatu peristiwa atau bagian yang dimainkan seseorang dalam suatu peristiwa. (Kamus Besar Bahasa Indonesia, 2008:1173).

Peranan menurut Ambarwati menunjukkan cakupan peran sebagai suatu konsep perihal apa yang dapat dilakukannya dalam suatu perusahaan. Seperti halnya dalam menjalankan sebuah perusahaan, perusahaan tentu tidak bisa lepas dari peranan seluruh elemen perusahaan yang di dalamnya termasuk Public Relation. (Ambarwati, 2009:15)

Berdasarkan beberapa pengertian diatas, dapat disimpulkan bahwa peranan dapat diartikan sebagai langkah yang diambil oleh seseorang atau kelompok dalam menghadapi suatu peristiwa. 


\section{Pengertian organisasi}

Organisasi adalah suatu kelompok orang dalam suatu wadah untuk tujuan bersama, sedangkan dalam kamus sosiologi, organisasi meruan sistem sosial yang dibentuk untuk mencapai tujuan-tujuan tertentu (Bisri Mustofa, 2008 : 216)

Organisasi adalah kesatuan (entity) sosial yang dikoordinasikan secara sadar; dengan sebuah batasan yang relatif dapat diidentifikasi; yang bekerja atas dasar yang relatif terus menerus untuk mencapai suatu tujuan bersama atau sekelompok tujuan. (Stephen P. Robbins)

Dari pengertian di atas dapat disimpulkan bahwa organisasi meruan sarana untuk melakukan kerjasama antara orang-orang dalam rangka mencapai tujuan bersama, dengan menggunakan sumber daya yang dimiliki.

\section{Pengertian partisipasi}

Pengertian yang sederhana tentang partisipasi dikemukakan oleh, dimana partisipasi dapat juga berarti bahwa pembuat keputusan menyarankan kelompok atau masyarakat ikut terlibat dalam bentuk penyampaian saran dan pendapat, barang, keterampilan, bahan dan jasa. Partisipasi juga berarti bahwa suatu kelompok mengenal masalah mereka sendiri, mengkaji pilihan mereka sendiri, membuat keputusan, dan memecahkan masalahnya. (Fasli Djalal dan Dedi Supriadi, $2001:$ 201-202)

Dalam buku karangan Soegarda Poerbakawatja partisipasi adalah suatu gejala demokrasi di mana orang diikutsertakan dalam perencanaan serta 13 pelaksanaan dari segala sesuatu yang berpusat pada kepentingan dan juga ikut memikul tanggung jawab sesuai dengan tingkat kematangan dan kewajibannya (Soegarda Poerbakawatja, 1981:251).

Dari pengertian tersebut dapat ditarik kesimpulan partisipasi adalah wujud dari peran serta masyarakat dalam aktivitas berupa perencanaan dan pelaksanaan untuk mencapai tujuan pembangunan masyarakat. Wujud partisipasi dapat berupa jasa, saran, ataupun dalam bentuk materi baik secara langsung maupun tidak langsung. 


\section{Pengertian Implementasi}

Menurut Nurdin Usman dalam bukunya yang berjudul Konteks Implementasi Berbasis Kurikulum mengemukakan pendapatnya mengenai implementasi atau pelaksanaan sebagai berikut : Implementasi adalah bermuara pada aktivitas, aksi, tindakan, atau adanya mekanisme suatu sistem. Implementasi bukan hanya sekedar aktivitas, melainkan suatu kegiatan yang terencana dan untuk mencapai tujuan kegiatan (Usman, 2002:70).

Menurut Guntur Setiawan dalam bukunya yang berjudul Implementasi Dalam Birokrasi Pembangunan mengemukakan pendapatnya mengenai implementasi, yaitu perluasan aktivitas yang saling menyesuaikan proses interaksi antara tujuan dan tindakan untuk mencapainya serta memerlukan jaringan pelaksana, birokrasi yang efektif (Setiawan, 2004:39).

Dari pengertian di atas dapat disimpulkan bahwa implementasi adalah bukan hanya sekedar aktivitas, melainkan suatu kegiatan yang terencana dan dilakukan secara sungguh-sungguh berdasarkan acuan aturan tertentu untuk mencapai sebuah tujuan kegiatan dimana untuk mencapai tujuan tersebut dibutuhkan jaringan pelaksana yang dapat dipercaya.

\section{METODE PENELITIAN}

Sementara pendekatan dalam Penelitian ini menggunakan pendekatan kualitatif, sifat data yang dikumpulkan adalah berupa data kualitatif, karena peneliti bermaksud mendiskripsikan, dan menggambarkan Peranan Organisasi Bina Pemuda yang berada di Desa Darungan Kecamatan Wlingi dalam peningkatan partisipasi di kegiatan masyarakat. Metode yang digunakan dalam menulis jurnal ini adalah metode kualitatif. Metode kualitatif sebagai prosedur penelitian yang menghasilkan data deskriptif berupa kata-kata tertulis atau lisan dari orang-orang dan perilaku yang diamati. Dalam penelitian kualitatif data yang diperoleh berupa informasi, keterangan dan berupa hasil-hasil pengamatan. Penelitian kualitatif hasil pengamatan tidak disajikan dalam bentuk numerik, melainkan dalam bentuk kata-kata sesuai dengan karakteristik dari pendekatan kualitatif hingga diperoleh pemahaman-pemahaman yang lebih mendalam dan 
lebih luas tentang pengamatan dibalik informasi selama berinteraksi di lapangan Bogdan dan Taylor (Moleong, 2001: 3).

Metode pengumpulan data dalam penelitian ini yaitu wawancara dan observasi, agar data yang diperoleh adalah data yang benar dan merupakan gambaran sebenarnya dari peranan Organisasi Bina Pemuda. Wawancara dilakukan pada bulan November dengan Amin selaku ketua Organisasi Bina Pemuda dan juga Syaifudin salah satu anggota Organisasi Bina Pemuda yang aktif.

\section{PEMBAHASAN}

\section{Konsep partisipasi}

1. Organisasi kepemudaan yang berdasarkan partisipasi masyarakat adalah salah satu bentuk pengorganisasian masyarakat. Hal ini berarti bahwa fasilitas untuk mengadakan sebuah kegiatan itu timbul dari masyarakat itu sendiri.

2. Kegiatan akan dilaksanakan oleh masyarakat sendiri. Artinya tenaganya dan penyelenggaraannya akan ditangani oleh anggota masyarakat itu sendiri

3. Apabila kegiatan itu diciptakan oleh masyarakat itu sendiri, ini berarti bahwa masyarakat itu memerlukan kegiatan tersebut. Sehingga adanya sebuah kegiatan di desa itu menunjukkan bahwa masyarakat perlu adanya kegiatan tersebut yang dilaksanakan dari masyarakat dan untuk masyarakat.

\section{Peranan Partisipasi Masyarakat}

Di dalam partisipasi setiap anggota masyarakat dituntut suatu kontribusi atau sumbangan. Kontribusi tersebut bukan hanya terbatas pada dana dan finansial saja tetapi dapat berbentuk daya (tenaga) dan ide (pemikiran). Dalam hal ini dapat disimpulkan dalam bentuk $4 \mathrm{M}$, yaitu tenaga (manpower), uang (money), material 
(benda-benda lain seperti kayu, bambu, beras, batu, dan sebagainya), dan idea tau gagasan (Mind).

Dari uraian tersebut dapat disimpulkan bahwa filosofi partisipasi masyarakat di kegiatan yang ada di desa adalah terciptanya keikutsertaan masyarakat desa dalam mengikuti sebuah kegiatan yang diadakan dari masyarakat, oleh masyarakat, dan untuk masyarakat. Masyarakat ikut menentukan arah atau strategi yang dilakukan oleh organisasi itu, ikut memikul beban dan bertanggung jawab dalam pelaksanaan kegiatan, serta memetik hasil dan manfaat dari terlaksananya kegiatan tersebut. Sebuah kegiatan akan berhasil jika fasilitas yang dibutuhkan ada dari masyarakat. Kegiatan juga terselenggara dengan baik jika panitia penyelenggara dan partisipasi juga ada dari masyarakat. dan semua kegiatan yang dilaksanakan itu juga untuk kepentingan masyarakat.

Masyarakat di desa Darungan sudah ikut berkontribusi dalam kegiatan yang diadakan organisasi Bina Pemuda di desa. Mereka menyumbangkan tenaga mereka, ikut membantu dalam pelaksanaan demi berjalannya kegiatan dengan baik, serta memberi masukan untuk anggota organisasi mengenai hal-hal apa kiranya yang kurang dan perlu diperbaiki. Masyarakat menyadari bahwa keberhasilan sebuah kegiatan tidak lepas dari peran aktif masyarakat. Karena terciptanya sebuah kegiatan dari masyarakat tersebut ditujukan untuk masyarakat itu sendiri

\section{Peningkatan Partisipasi Masyarakat}

Di dalam sebuah organisasi pasti memiliki sebuah program kerja. Dari program kerja itu nanti akan diimplementasikan ke dalam bentuk nyata yaitu terlaksananya sebuah kegiatan. Dari terlaksananya sebuah kegiatan itu tadi bisa dikatakan berhasil atau tidak dapat dilihat dari bagaimana partisipasi yang diberikan oleh masyarakat, baik atau kurang baik. Jika partisipasi yang diberikan oleh masyarakat baik, serta terdapat juga kontribusi-kontribusi yang diberikan oleh masyarakat itu menunjukkan keberhasilan suatu kegiatan tersebut. Tinggal bagaimana cara organisasi ini bisa menarik perhatian masyarakat agar mau dan 
ikut berkontribusi serta berpartisipasi dalam kegiatan-kegiatan yang diadakan oleh sebuah organisasi tersebut.

Sama halnya dengan Organisasi Bina Pemuda. Dalam pengimplementasian program kerjanya organisasi ini melakukan beberapa hal untuk meningkatkan partisipasi masyarakat misalnya dengan memberi tahu akan pentingnya kegiatan tersebut. Dan dikarenakan masyarakat Desa Drungan sudah mengetahui kegiatan-kegiatan yang dilaksanakan oleh organisasi ini maka itu akan lebih mempermudah untuk meningkatkan keikutsertaan masyarakat desa. Karena masyarakat Desa Darungan sendiri juga sudah menyadari bahwa kegiatan yang dilaksanakan oleh organisasi ini juga untuk kepentingan bersama.

Dengan beberapa hal yang dilakukan oleh organisasi Bina Pemuda untuk menarik perhatian tersebut maka keberhasilan terlksananya sebuah kegiatan itu akan terlihat. Masyarakat Desa Darungan menjadi lebih sadar akan betapa pentingnya berpartisipasi di kegiatan yang dilaksanakan oleh organisasi Bina Pemuda karena kegiatan tersebut juga untuk kepentingan masyarakat Desa Darungan itu sendiri.

\section{Pengenalan Program Kerja Organisasi Bina Pemuda (Organisasi Kepemudaan di desa Darungan)}

Organisasi adalah suatu kelompok orang dalam suatu wadah untuk tujuan bersama, sedangkan dalam kamus sosiologi, organisasi meruan sistem sosial yang dibentuk untuk mencapai tujuan-tujuan tertentu (Bisri Mustofa, 2008 : 216)

Organisasi Bina Pemuda merupakan suatu organisasi yang beranggotakan pemuda-pemuda yang berada di lingkungan masyarakat Desa Darungan yang di dalamnya terdapat sebuah kepengurusan. Kepengurusan di Bina Pemuda desa Darungan diharapkan memiliki tanggung jawab dalam peningkatan partisipasi masyarakat dan mengembangkan kegiatan-kegiatan yang dilaksanakan di lingkungan desa. Peningkatan kinerja organisasi dapat dilakukan dengan cara mengadakan program-program yang dapat membuat sebuah kemajuan bagi organisasi tersebut. Ide dan gagasan yang diberikan oleh para anggota dapat menjadikan organisasi ini mengalami kemajuan yang dapat terlihat dari 
pelaksanaan kegiatannya. Ide tersebut bisa diperoleh dari anggota Organisasi Bina Pemuda itu sendiri ataupun saran dari masyarakat.

Berikut ini akan di paparkan hasil wawanacara dan observasi peneliti dari beberapa narasumber terkait dengan program kerja Bina Pemuda (Organisasi Kepemudaan) dalam meningkatkan partisipasi di kegiatan masyarakat. Dalam kaitannya dengan program kegiatan Organisasi Bina Pemuda, Syaifudin selaku salah satu anggota Organisasi Bina Pemuda yang akitf. Beliau mengatakan seperti ini:

Kegiatan yang diadakan organisasi ini dari tahun ke tahun itu biasanya ya kegiatan-kegiatan pemuda, atau biasanya memeriahkan hari ulang tahun RI itu mereka yang mengadakan lomba-lomba ya untuk anak-anak ada, untuk orang dewasa juga ada seperti panjat pinang untuk memperabutkan hadiah yang sudah disediakan panitia. Mereka juga biasanya gotongroyong untuk membersihkan desa dan dibantu oleh masyarakat desa juga. Biasanya ini diadakan satu bulan sekali. Lalu mereka juga biasanya membantu masyarakat desa yang terkena musibah atau ada keluarga yang sedang berduka cita. Ya kegiatan-kegiatan semacam itu lah yang menjadi program kerja organisasi ini (Syaifudin)

Peneliti juga mewawancarai Amin selaku ketua organisasi dan beliau berkata seperti ini

Kalau program yang dilakukan oleh organisasi ini sih ya hampir sama dengan organisasi-organisasi pemuda lainnya, hanya saja dalam Organisasi Bina Pemuda ini ada beberapa orang yang merangkap di 2 seksi bidang yang berbeda. Itu ya karena anggota organisasi ini tidak begitu banyak. Soalnya ada anggota yang sudah tidak aktif karena kesibukannya masing-masing. Ya ada yang kerja, ada yang usaha. Tapi ya mereka usahakan biasanya tetap ikut membantu saat ada kegiatan masyarakat di desa. Program kerja organisasi ini tujuannya kan 
meramaikan desa dengan kegiatan yang positif ya biar masyarakat itu selain cuman kerja aja itu biar keluar dari rumah gitu, biar sosial nya masih ada. Jadi masih sambung sama warga. Kalau untuk pembagian tugasnya tidak ada yang khusus, semua anggota rapat setelah dicapai mufakat baru dibagi tugas. Pembagian tugasnya juga sama seperti umumnya, ada yang bertugas memberi pengumuman kepada warga, ada yang menyiapkan peralatan dan perlengkapan, ada yang mengajukan anggaran, ya seperti itu (Amin)

Peneliti juga ining mengetahui dari sudut pandang warga, apakah warga sendiri mengetahui dan mengikuti program kerja atau kegiatan-kegiatan yang dilaksanakan oleh Organisasi Bina Pemuda. Sehingga peneliti melakukan wawancara dengan Wildan, salah satu warga desa Darungan mengenai program kerja Organisasi Bina Pemuda. Berikut paparan hasil wawancara tersebut

Program kerja Organisasi Bina Pemuda itu ya kegiatan-kegiatan yang di desa itu setahu saya. Kayak bersih desa itu yang rutin dilakukan 2 bulan sekali. Terus ada juga pentas seni, terus lomba-lomba peringatan HUT RI itu juga rutin dilakukan setiap tahunnya. Banyak anak-anak pada ikut lomba, terus ada juga yang menghias jalan dengan lampu-lampu itu biar bagus. Warga sangat antusias saat organisasi ini mengadakan sebuah kegiatan, soalnya organisasi ini salah satu organisasi yang aktif dalam berkegiatan. Anggota organisasi ini biasanya dibantu sama warga sekitar dan pemuda-pemuda lainnya. Kalau kegiatan-kegiatan yang sering diadakan organisasi Bina Pemuda itu ya seperti itu setahu saya (Wildan)

Dari hasil wawancara di atas menunjukkan bahwa secara umum program kerja yang dilakukan Organisasi Bina Pemuda telah dilaksanakan dengan baik. Kegiatan-kegiatan rutin yang diadakan organisasi ini seperti bersih desa, pentas seni, gotong royong, peringatan hari ulang tahun RI, dan kegiatan-kegiatan desa lainnya telah terlaksana dengan baik dan rutin dijalankan. Untuk pembagian tugas 
bagi para anggota tidak ada yang khusus, hanya saja sesuai dengan bagian masing-masing. Ada yang bertugas memberi pengumuman, menyebarkan undangan, menyiapkan perlengkapan dan peralatan, dan mengajukan dana.

Peneliti mendapatkan info dari salah satu warga bahwa program-program kerja Organisasi Bina Pemuda sudah diketahui oleh masyarakat desa terutama orang-orang yang sering membantu organisasi ini dalam melaksanakan kegiatan di masyarakat, hal ini disebabkan karena kegiatan-kegiatan yang dilaksanakan oleh organisasi ini sudah menjadi kebiasaan bagi masyarakat. Bersih desa di desa Darungan dilakukan oleh anggota organisasi Bina Pemuda dibantu dengan warga desa bergotong royong membersihkan desa. Perayaan hari ulang tahun RI yang dimeriahkan dengan mengadakan lomba 17-an yang setiap tahun rutin dilaksanakan.

Kegiatan-Kegiatan yang rutin dijalankan seperti itu menjadi kebiasaan sehingga masyarakat menjadi hafal tentang program kerja Organisasi Bina Pemuda. Dengan demikian hampir seluruh program kerja yang sudah di jalankan oleh Organisasi Bina Pemuda telah di ketahui masyarakat sekitar. Hal ini di buktikan begitu antusianya masyarakat ketika kegiatan di lakukan. Antusias ini ditunjukkan dari anak-anak yang bersemangat mengikuti lomba, serta masyarakat yang dengan suka rela membantu saat diadakannya kegiatan, serta kontribusi yang diberikan masyarakat terhadap pelaksanaan kegiatan oleh organisasi ini. Kontribusi yang diberikan oleh masyarakat juga ada. Ini membuktikan bahwa kegiatan yang di lakukan dan di laksanakan menyentuh semua golongan masyarakat. Artinya Organisasi Bina Pemuda telah berhasil mengenalkan program kegiatannya ke masyarakat desa dan melaksanakannya dengan baik.

\section{Implementasi Program Kerja Organisasi Bina Pemuda dalam Meningkatkan Partisipasi di Kegiatan Masyarakat}

Dari segi etimologis kata partisipasi merupakan pinjaman dari bahasa Belanda participatie atau dalam bahasa Inggris Participation. Dalam bahasa Latin disebut Participatio yang berasal dari kata kerja Partipare yang berarti ikut serta, sehingga partisipasi mengandung pengertian aktif yaitu adanya kegiatan atau 
aktivitas (Le Pank : 2014). Sedangkan dalam KKBI (Kamus Besar Bahasa Indonesia) partisipasi berarti, perihal turut berperan serta dalam suatu kegiatan, keikutsertaan, peran serta. (KBBI Online : 2012)

Implementasi program kerja Organisasi Bina Pemuda ke dalam bentuk sebuah kegiatan diharapkan bisa mengembangkan strategi organisasi ini ke dalam bentuk tindakan nyata. Jadi program kerja yang telah disusun dan dimusyawarahkan diterapkan ke dalam bentuk tindakan nyata berupa kegiatankegiatan yang dilaksanakan di desa.

Berikut ini akan di paparkan hasil wawanacara dan observasi peneliti terhadap beberapa narasumber terkait dengan implementasi program kerja Organisasi Bina Pemuda dalam meningkatkan partisipasi masyarakat dalam mengikuti kegiatan di desa. Dalam kaitannya dengan implementasi program kerja untuk meningkatkan partisipasi di kegiatan masyarakat Amin selaku ketua Organisasi Bina Pemuda memaparkan sebagai berikut:

Iya jelas pengaruhnya besar ya. Organisasi ini itu sangat membantu sekali dalam pengadaan kegiatan masyarakat seperti itu. Mereka yang menyusun rencana seperti apa yang mereka mau adakan. Mereka merencanakannya dengan baik, membagi tugas kepada setiap anggota, serta mencari dana untuk terlaksanya kegiatan yang akan diadakan. Setelah diadakannya rapat dan juga menemukan hasil mufakatnya mereka memberikan pengumuman kepada masyarakat. Jadi semua kegiatan yang direncanakan organisasi ini kan dimasukkan ke dalam program kerja mereka, nah program kerja mereka itu nanti yang akan dilaksanakan dalam sebuah tindakan nyata yaitu terbentuknya sebuah kegiatan di desa. Kegiatan-kegiatan yang sudah mereka susun di program kerja itu rutin dilaksanakan. Salah satunya seperti yang saya sebut tadi bersih desa rutin dijalankan sebulan sekali, peringatan HUT RI rutin diperingati setahun sekali, terus ada juga biasanya peringatan hari apa gitu anak-anak mengadakan pentas seni seperti wayang, dan antusias dari masyarakat itu baik sekali (Amin) 
Kemudian peneliti mewancarai kembali terkait hambatan-hambatan yang di hadapi Organisasi Bina Pemuda dalam pengimplemtasian program kerja, beliau mengakatan sebagai berikut:

Yah yang namanya organisasi ya pasti kalau mau mengadakan acara itu pasti butuh dana, dan butuh sumber daya manusia yang cukup untuk menangani semuanya. Kadang-kadang kita terbatas sumber daya manusianya, Kalau masalah dana kita biasa menerima bantuan dana dari RT. Sampai saat ini masalah dana bisa diatasi. Kalau masalah sumber daya nya itu yang agak susah. Waktu rapat itu yang datang panitia nya biasanya kurang, jadi mau mebagikan tugas ke setiap panitia itu sulit. Kadang-kadang kalau acara mepet terus masih banyak yang harus dilakukan itu juga yang membuat prosesnya jadi agak terhambat (Amin)

Berdasarkan hasil wawancara ketua Organisasi Bina Pemuda, Dalam implementasi program kerja Organisasi Bina Pemuda ke dalam bentuk sebuah kegiatan sebagian sudah berjalan dengan baik. Kegiatan-kegiatan yang sudah disusun dan dimusyawarahkan yang masuk dalam program kerja organisasi ini sudah dilaksanakan. Program kerja organisaisi ini seperti bersih desa, pentas seni, peringatan HUT RI, dan kegiatan-kegiatan desa lainnya sudah berjalan sesuai dengan program kerja mereka.

Namun sebuah organisasi dalam menjalankan sebauh kegiatan pasti ada beberapa hambatan yang dihadapi. Sama halnya dengan organisasi Bina Pemuda. Dalam implementasi program kerjanyanya walaupun sudah berjalan dengan baik, namun ada saja kendala-kendala yang terkadang membuat kegiatan tersebut terhambat, terutama dari sumber daya manusianya.

Dalam hambatan implementasi program lebih fokus pada sumber daya manusianya yang kurang. Hal tersebut bisa dilihat ketika rapat acara sedang di musyawarahkan, kedatangan panita kurang yang mengakibatkan sulitnya membagi tugas kepada setiap panitia. Pembagian tugas yang sulit inilah hambatan yang membuat implementasi program menjadi terhambat. Tetapi biasanya pembagian tugas disiasati dengan 1 orang merangkap memiliki beberapa tugas Ini yang harus segera di carikan jalan keluar, yaitu dengan mencari generasi remaja 
secepat mungkin sebagai penerus anggota-anggota yang sudah tidak aktif. Dan karena yang anggota yang tidak begitu banyak, organisasi ini biasanya juga mengalami sedikit kesulitan saat pelaksanaan kegiatan yang membuat panitia kurang. Hal ini bisa disiasati dengan meminta beberapa warga untuk membantu saat pelaksaan kegiatan. Untuk mengatasi masalah ini sebenarnya dengan cara mencarikan anggota baru. Tetapi mencari anggota baru tidak mudah. Sedikit pemuda-pemuda yang mau bergabung ke dalam Organisasi Bina Pemuda karena bermacam-macam alasan. Walaupun menemui hambatan-hambatan tersebut tetapi organisasi ini sanggup untuk menghadapinya.

\section{Dampak Implementasi Program Kerja Organisasi Bina Pemuda dalam Meningkatkan Partisipasi di Kegiatan Masyarakat}

Secara sederhana implementasi bisa diartikan pelaksanaan atau implementasi. Majone dan Wildavsky mengemukakan implementasi sebagai evaluasi (Nurdin dan Usman : 2002). Sedangkan Browne dan Wildavsky mengemukakan bahwa implementasi adalah perluasan aktivitas yang saling menyesuaikan (Nurdin dan Usman. 2004 : 70)

Pengertian diatas memperlihatkan bahwa kata implementasi merujuk pada aktivitas, namun bukan sekedar aktivitas, tetapi suatu kegiatan yang terencana dan dilakukan secara sungguh-sungguh berdasarkan aturan tertentu untuk mencapai tujuan kegiatan.

Dalam kaitanya dengan dampak adanya program kegiatan yang dilaksanakan Organisasi Bina Pemuda, peneliti mewawancarai Syaifudin selaku anggota yang akif dalam organisasi tersebut, beliau mengatakan sebagai berikut

Kita nggak bisa ngukur ya seberapa persen sih dampak dari kegiatankegiatan yang dilakukan oleh organisasi ini terhadap partisipasi masyarakat. Namun jika kita lihat dengan adanya program Organisasi Bina Pemuda ini justru bisa menambah motivasi dan semangat masyarakat sekitar kita untuk lebih peduli terhadap kegiatan-kegiatan desa. Kalau misalnya organisasi ini tidak mengadakan kegiatan, ya mungkin masyarakat kan jadi kurang begitu aktif, cuman di rumah dan 
jarang kumpul. Saya ambil contoh kalau misalnya ada kerja bakti nah itu kan organisasi ini dibantu oleh masyarakat sekitar, jadi istilahnya dengan adanya sebuah kegiatan ini masyarakat keluar dari rumah dan bertemu dengan orang-orang warga desa yang biasanya jarang mereka temui karena alasan pekerjaan. Jadi sisi positifnya ya itu (Syaifudin)

Dari implementasi program kerja Organisasi Bina Pemuda dalam meningkatkan partisipasi di kegiatan masyarakat, dampak positif telah di rasakan masyarakat dengan adanya kegiatan atau program yang dilaksanakan Organisasi Bina Pemuda. Program-program Organisasi Bina Pemuda sudah diketahui masyarakat sejak lama dan rutin dilakukan, hal ini menjadi sebuah tanggapan positif masyarakat.

Seperti yang dikatakan Syaifudin dengan diadakannya kegiatan di desa yang diadakan oleh Organisasi Bina Pemuda akan menumbuhkan jiwa sosial masyarakat. Masyarakat akan saling membantu di dalam kegiatan tersebut. Masyarakat yang jarang bertemu atau berkomunikasi karena kesibukan masingmasing juga akan bertemu sehingga tidak menyebabkan hilangnya rasa persaudaraan.

Dampak yang positif menghasilkan harapan yang baik pula dari masyarakat sekitar, harapan terus adanya kegiatan dan keberadaan Organisasi Bina Pemuda menjadi harapan utama masyarakat dalam berkegiatan, hal ini yang membuktikan Organisasi Bina Pemuda telah berhasil meningkatkan kepercayaan masyarakat dalam peningkatan partisipasi di kegiatan masyarakat.

\section{PENUTUP}

\section{Kesimpulan}

Partisipasi masyarakat di kegiatan yang ada di desa adalah terciptanya keikutsertaan masyarakat desa dalam mengikuti sebuah kegiatan yang diadakan dari masyarakat, oleh masyarakat, dan untuk masyarakat. Masyarakat ikut menentukan arah yang dilakukan oleh organisasi itu, ikut memikul beban dan bertanggung jawab dalam pelaksanaan kegiatan, serta memetik hasil dan manfaat dari terlaksananya kegiatan tersebut. Sebuah kegiatan akan berhasil jika fasilitas 
yang dibutuhkan ada dari masyarakat. Kegiatan juga terselenggara dengan baik jika panitia penyelenggara dan partisipasi juga ada dari masyarakat. dan semua kegiatan yang dilaksanakan itu juga untuk kepentingan masyarakat. Keberhasilan sebuah kegiatan bisa dilihat dari partisipasi masyarakat dalam sebuah kegiatan. Selain itu masyarakat juga bisa ikut berkontribusi dalam bentuk tenaga, dana, peralatan, dan juga ide.

Organisasi Bina Pemuda telah berhasil mengenalkan program kegiatannya ke masyarakat desa. Kegiatan-kegiatan yang diadakan organisasi ini seperti bersih desa, pentas seni, gotong royong, peringatan hari ulang tahun RI, dan kegiatankegiatan desa lainnya terlaksana dengan baik dan sesuai rencana, dan juga partisipasi masyarakat sangat baik mulai dari anak-anak hingga orang dewasa.

Program kerja Organisasi Bina Pemuda sebagian sudah berjalan dengan baik, kegiatan-kegiatan yang dilakukan sesuai dengan rencana yaitu meramaikan desa dengan kegiatan-kegitan positif. Namun ada beberapa hal yang menjadi kendala dalam melaksanakan kegiatan ini yaitu kurangnya sumber daya manusia.

Dampak positif telah dirasakan masyarakat desa Darungan, kegiatankegiatan masyarakat yang telah dilaksanakan akan menumbuhkan jiwa sosial masyarakat. Masyarakat akan saling membantu di dalam kegiatan tersebut. Masyarakat yang jarang bertemu atau berkomunikasi juga akan bertemu sehingga tidak menyebabkan hilangnya rasa persaudaraan. Jadi masyarakat akan lebih peduli terhadap keadaan social. Dampak yang positif menghasilkan harapan yang baik pula dari masyarakat sekitar, harapan terus adanya kegiatan dan keberadaan Organisasi Bina Pemuda menjadi harapan utama masyarakat dalam berkegiatan,

Dari keseluruhan tersebut bisa dilhat bahwa program kerja organisasi ini yang telah diimplementasikan ke dalam tindakan nyata yaitu sebuah kegiatan yang ada di desa Darungan mendapat tanggapan yang positif. Bisa dilihat dari partisipasi masyarakat yang baik serta kontribusi yang diberikan oleh masyarakat yang membuat tumbuhnya kepercayaan masyarakat kepada organisasi ini dalam mengadakan sebuah kegiatan. Sehingga bisa disimpulkan bahwa Organisasi Bina Pemuda memiliki peranan dalam meningkatkan partisipasi di kegiatan masyarakat 
di lingkungan desa Darungan. Hal ini bisa di lihat dari antusias masyarakat dalam setiap pelaksanaanya.

\section{DAFTAR PUSTAKA}

Afriyanto Dwi, Desember 2014, Peranan Pengurus Karang Taruna Meningkatkan Kinerja Organisasi

Ambarwati, R,E., Wulandari, D, 2009. Jogjakarta: Mitra Cendika Press

Badiyanta, Zulkifli Akbar, dan Karsono. 2009. Meningkatkan Kompetensi dan Daya Saing Pemuda dalam Menghadapi Krisis Global. Jakarta: Komenegpora

Bisri Mustofa. 2008. Kamus Lengkap Sosiologi. Jogjakarta: Panji Pustaka.

Djalal, Fasli dan Supriadi, Dedi. 2001. Reformasi Pendidikan dalam Konteks Otonomi Daerah. Yogyakarta: Adicita

Guntur Setiawan. 2004. Implementasi dalam Birokrasi Pembangunan. Bandung: Remaja Rosdakarya Offset

Lexy J Moleong. 2001. Metodologi Penelitian Kualitatif. Bandung: PT Remaja Rosda Karya.

Usman, Nurdin. 2002. Konteks Implementasi Berbasis Kurikulum. Jakarta: PT Raja Gravindo Persada 